\title{
Sixth London International Youth Science Fortnight \\ London, 6-I7 August 1964
}

The sixth International Youth Science Fortnight, organized by the World Friendship Federation and the British Association for the Advancement of Science, was attended by 500 students from twenty-one countries as well as 1,000 young British delegates from all over England. 21 students ( 11 boys, 10 girls) selected from universities in Tokyo were present from Japan.

The opening ceremony was presided over by Sir John Cockcroft, F.R.S., messages were received from the British Prime Minister and Minister of Education and from the Moscow Medical Academy. Two guest speakers, Sir Christopher Hinton, F.R.S., and Sir Cyril Hinshelwood, F.R.S., spoke about recent scientific progress and its relation to social change.

A demonstration of several scientific experiments, such as the testing of artificial limbs, orthopedic devices for thalidomide babies and audio-visual and film demonstrations of neurosurgery, etc., were presented by outstanding researchers from the U.S.A., the U.S.S.R., Great Britain, Austria and Yugoslavia, which gave the audience exciting opportunities to develop an understanding of the recent advances of medicine.

Group meetings were organized according to scientific subjects, for instance, physics, chemistry, biology, biochemistry (medicine), mathematics, engineering and general science in which discussions followed a lecture given by a specialist in each field.

The meeting provided a place for not only the intellectual growth of young people through scientific understanding, but also a place for social gatherings which were greatly appreciated by the participants from distant countries.

Toshio IrITani, Tokai University, Tokyo

\author{
Die erste Weltjugendkonferenz der UNESCO \\ Grenoble, 23. August-I. September I96 $64_{4}$
}

An der ersten Weltkonferenz über Jugendfragen nahmen Delegierte aus 72 Mitgliedstaaten der UNESCO, Vertreter von fünf Sonderorganisationen der Vereinten Nationen, von vier weiteren zwischenstaatlichen Organisationen und von 36 nichtstaatlichen internationalen Organisationen, die den Konsultativstatus mit der UNESCO besitzen, teil.

Diese bunte, große Teilnehmerschaft, der stilvolle gesellschaftliche Rahmen, die Publizität, die wirklich eindrucksvolle organisatorische Durchführung dieses Unternehmens, die hohen Erwartungen, die zu Beginn der Konferenz - insbesondere in der Eröffnungsansprache des Generaldirektors der UNESCO, M. René Maheu zum Ausdruck kamen, und nicht zuletzt das fast etwas naiv klingende selbstzufriedene Pathos, mit dem ausgewählte Teilnehmer die einstimmig angenommenen Ergebnisse der Konferenz bei der Abschluß-Sitzung feierten, - all dies zusammen genommen mochte vielen Teilnehmern und Beobachtern das Gefühl vermitteln, einem grossen „historischen" Ereignis beigewohnt zu haben.

Ohne Zweifel muß es für viele Teilnehmer ein starkes Erlebnis gewesen sein. Den Vertretern der jungen Länder bot diese Weltkonferenz ein Forum, auf dem sie ihre 